\begin{tabular}{|c|c|}
\hline \multirow{3}{*}{ 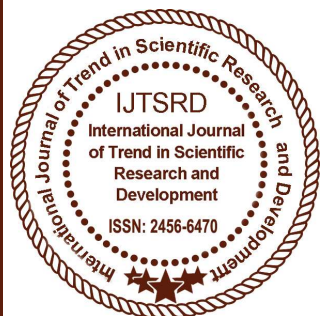 } & $\begin{array}{l}\text { International Journal of Trend in Scientific } \\
\text { Research and Development (IJTSRD) }\end{array}$ \\
\hline & International Open Access Journal \\
\hline & ISSN No: 2456 - 6470 | www.ijtsrd.com | Volume - 2 | Issue - 2 \\
\hline
\end{tabular}

\title{
Study of the Teachers' Opinion about Inculcating Values among the Students
}

\author{
Dr. Payal D. Patel \\ Assistant Professor, Bhagwan Mahavir College of Education, \\ Bharthana, Vesu, Surat
}

\section{INTRODUCTION}

The prime concern of education is to evolve the good, the true $\&$ the divine in man so as to establish a moral life in the world. The main function of education is to enrich the character. Since education is a powerful weapon of social change and human progress, it is also a powerful instrument to inculcate values in an individual. Therefore all the educational institute including schools, colleges \& many more have greater responsibility to inculcate values through education.

Value education is rooted in Indian Philosophy and Culture and in grained in every tradition of Indian culture. The Vedas and Upanishads form the source of inspiration for value education. In the Vedic period, in Ashram system of education, the Guru insisted his student to follow certain values throughout his life. University education commission 1948-49 mentioned the various aspects of morality as : loyalty, courage, discipline, self- sacrifice and spiritiuality.

\section{Topic of The Study}

As the teacher of teacher trainees reasher feel that there is more important to know how we inculcate values in students therefore the topic for this study was as follow

\section{'Study Of The Teachers' Opinion About} Inculcating Values Among The Students"

\section{Objectives of the Study}

Objectives of this study were as follow
1) To study the opinion of teachers about inculcate values in students.

2) To study the opinion of teachers about ways to make value education more effective.

\section{Questions of the Study}

Questions of this study were as follow

1) Which type of opinion teachers have about inculcate values in students?

2) Which type of ways teachers suggest to make value education more effective?

\section{Importance of the Study}

From this study we know the opinion about teachers to inculcate values in students and also know the various ways to inculcate values. Value education awakens curiosity, development of proper interests, attitudes, values and capacity to think and judge about oneself. It helps in promoting social and natural Integration. Also we can provide a good civilized person to the society. We can help society to control over many crimes from this inculcate values in students.

\section{Limitations of this Study}

This study limited only for the primary teachers of the Surat city. In this study used only closed end and open questionnaire to collect the data.

7. Population and Sample of the Data 
For this study all the primary teachers teaches in the primary school of Gujarat became the population. From this population Only teachers of Surat city are selected as sample of this study. Total Eighty primary teachers are selected as random sample method.

\section{Research Method of this Study}

To study the opinion of teachers about inculcate values among the students Survey method was use to collect data.

\section{Construction of the Tool}

For this study first to know the Opinion of teachers about inculcate values in students researcher used self made close end questionnaire and second to study the ways to inculcate values in students researcher used open end questionnaire.

\section{Data Collection}

To collect the data first took the permission of selected school's principal and then meet the teachers of particular school. First explain the objective of this study then gave them questionnaire to fill and collect the data.

\section{Data Analyses}

To collect the data on close end questionnaire percentage used to analyses of data and for open end questionnaire qualitative analyses was done for analyses of data.

\section{Findings}

1) Common values should be re-discovered to unite human beings with the general decline of traditional values.

2) Teachers pass values to the students both consciously and un consciously through their conduct in and out of classrooms.

3) Students might face more complicateddecision making situation about issues involving values.

4) We have to decrease in Juvenile Delinquency to youth who under goes the process of personal growth.

5) Teachers serve as role model to students in school, they play a major role in inculcating their ethical behavior.
6) Peers in school also help in diffuse cheating, lying, stealing and consideration for others.

7) Rules and regulations in the school are also help to inculcate values in students in formal way.

8) The students should be encouraged to respect and treat others kindly.

9) When the students sees the model showing concern for others, motivating them for their good deeds and cooperating and helpful with their academic issues, the students learn them by observing and imitate it with fellow peers.

10) The students are taught basic marals and values by emphasizing the idea through many activities, stories and tales, which will encourage them to engage in more helping behaviours.

11) The teacher should appreciate the students for developing pro-social behavior, especially for any specific action they have done to help others.

12) Values can be inculcated only through situations deliberately planned while teaching the subjects.

\section{Conclusion}

"Education without values, as useful as it seems rather to make man a more clever devil." C.S.Lewis

Socialist,Secular,Democratic,Justice,Liberty,Equality, Fraternity,Dignity of the individuals and integrity of the nation are the ideal conditions in the Constitution. Our values in life must draw their inspiration from these ideals.

\section{$\underline{\text { References }}$}

1) Dhankar,Neerja(2010). Value Education in Schools. New Delhi: Jain Book Agency.

2) Patil,Yojana(2015).Value Education:Need Of The Hour. Pasaaydaan aafoundation.

3) Singh,Nisha and Rani,Anju(2013). Various Approaches of Values Inculcation. In Journal of Social Welfare and Management,Vol.5,No.4,OctDec 2013.

4) Singh,Y.K. and Nath,Ruchita(2008). Value Education. New Delhi:A.P.H.Publishing Corporation. 